Check for updates

Cite this: RSC Adv., 2018, 8, 14164

Received 26th February 2018

Accepted 9th April 2018

DOI: $10.1039 / \mathrm{c} 8 \mathrm{ra} 01689 \mathrm{e}$

rsc.li/rsc-advances

\section{Crystal structure and luminescence properties of a novel single-phase orange-red emitting phosphor $\mathrm{Ca}$ La $\left(\mathrm{PO}_{4}\right)_{7}: \mathrm{Sm}^{3+}$}

\begin{abstract}
Bin Ma, (D) *a Xiaoqin Ma, ${ }^{\mathrm{b}}$ Tonghui Xu, ${ }^{\mathrm{a}}$ Ke Su${ }^{\mathrm{a}}$ and Qianxin Zhang ${ }^{\mathrm{a}}$
$\mathrm{Ca}_{9} \mathrm{La}_{1-x}\left(\mathrm{PO}_{4}\right)_{7}: x \mathrm{Sm}^{3+}$ phosphors $(0.01<x<0.25)$ were synthesized via high temperature solid-state reaction. Their properties including crystal structure, decay performance, thermal stability and photoluminescence were examined in detail. Phase analysis indicated that the phosphors crystallized in a rhombohedral structure, and the emission spectra of the phosphors consisted of four peaks centered around 570, 607, 653, and $714 \mathrm{~nm}$, attributed to $\mathrm{Sm}^{3+}$ ions transitions ${ }^{4} \mathrm{G}_{5 / 2} \rightarrow{ }^{6} \mathrm{H}_{\mathrm{J}}(\mathrm{J}=5 / 2,7 / 2,9 / 2$, and $11 / 2$, respectively). The optimal $\mathrm{Sm}^{3+}$ doping content was $0.12 \mathrm{~mol}$ and the $\mathrm{Ca} \mathrm{L}_{2}\left(\mathrm{PO}_{4}\right)_{7}: \mathrm{Sm}^{3+}$ phosphor also exhibited better thermal stability compared to other phosphors. In addition, the mechanism behind the energy transfer between $\mathrm{Sm}^{3+}$ ions was determined to be dipole-dipole interactions as described by Dexter theory. The results indicated that as orange-red phosphors, CagLa $\left(\mathrm{PO}_{4}\right)_{7}: \mathrm{Sm}^{3+}$ phosphors were promising candidates for being integrated into white light emitting diodes.
\end{abstract}

\section{Introduction}

As a new generation of illumination light sources, white light emitting diodes (w-LEDs) have received much attention. Their main advantages over conventional light sources are extended lifetime, better security and reliability as well as higher energyefficiency. ${ }^{1-6}$ In general, w-LEDs can be achieved with the following two approaches: in the first method a yellow phosphor such as $\mathrm{Y}_{3} \mathrm{Al}_{5} \mathrm{O}_{12}: \mathrm{Ce}^{3+}$ (YAG:Ce) is integrated into a blue LED chip (as InGaN-based chip); ${ }^{7}$ in the second one, a near-UV (n-UV) LED chip, emitting in the $350-420 \mathrm{~nm}$ spectral range, is incorporated in a tri-color phosphor (i.e. blue, green, and red). ${ }^{8}$ However, the former method suffers from a rather high color temperature $(>4500 \mathrm{~K})$ and poor color-rendering index (CRI < 75) resulted from the weak emission in the visible red range. ${ }^{9}$ The second method can better control the w-LED colors, still, it is a great challenge to obtain orange or red phosphors with a high stability and brightness, so this issue is necessary to addressed.

Lanthanides are commonly used in displays and lighting devices thanks to the $5 \mathrm{~d} \rightarrow 4 \mathrm{f}$ or $4 \mathrm{f} \rightarrow 4 \mathrm{f}$ transitions. ${ }^{4}$ Red and orange-red emitting phosphors can be realized by doping lanthanides with $\mathrm{Eu}^{3+}$ or $\mathrm{Sm}^{3+}$ ions and exploiting $4 \mathrm{f} \rightarrow 4 \mathrm{f}$ transitions. However, $\mathrm{Eu}^{3+}$ doped phosphors display efficient luminescence only under n-UV excitation, which limits their

${ }^{a}$ Qinghai Provincial Key Laboratory of New Light Alloys, Qinghai Provincial Engineering Research Center of High Performance Light Metal Alloys and Forming, Qinghai University, Xining 810016, P. R. China. E-mail: mabinss@126.com; Fax: +86-0971-5363128; Tel: +86-0971-5363128

${ }^{b}$ Analytical Instrumentation Center, Qinghai Normal University, Xining 810016, P. R. China application in w-LEDs. ${ }^{5}$ While $\mathrm{Sm}^{3+}$ doped phosphors can be more easily stimulated by a blue region radiation. Moreover, $\mathrm{Sm}^{3+}$ doped phosphors can act as orange-red emitters due to the ${ }^{4} \mathrm{G}_{5 / 2} \rightarrow{ }^{6} \mathrm{H}_{\mathrm{J}}$ (with $J=5 / 2,7 / 2,9 / 2$, and $11 / 2$ ) transitions. ${ }^{10}$ These features have motivated intense researches on compounds such as $\mathrm{Sr}_{3} \mathrm{Lu}\left(\mathrm{PO}_{4}\right)_{3}: \mathrm{Sm}^{3+},{ }^{11} \mathrm{Ba}_{3} \mathrm{Lu}\left(\mathrm{PO}_{4}\right)_{3}: \mathrm{Sm}^{3+}{ }^{12} \mathrm{NaSrVO}_{4}: \mathrm{Sm}^{3+}$ (ref. 13) and $\mathrm{KLaSr}_{3}\left(\mathrm{PO}_{4}\right)_{3} \mathrm{~F}: \mathrm{Sm}^{3+} \cdot \mathbf{1 4}^{\mathbf{4}}$

Recently, multiple examples of phosphates with whitlockite crystal structure fabricated based on $\mathrm{M}_{9} \mathrm{R}\left(\mathrm{PO}_{4}\right)_{7}$ compounds, in which $\mathrm{M}=\mathrm{Ca}$ or $\mathrm{Sr}$ and $\mathrm{R}=\mathrm{La}, \mathrm{Y}, \mathrm{Sc}, \mathrm{Gd}$, or Bi, have demonstrated the feasibility for them to be applied as host materials for phosphors. Specifically, such phosphates compounds possess good thermal stability, ${ }^{15}$ and perfect charge stabilization allowed by the rigid tetrahedral matrix of the phosphate. ${ }^{16,17}$ Besides, they can be synthesized in an easy and low-cost method. ${ }^{18}$ Currently, the luminescence of rare-earth ions doped whitlockite-type phosphate have been intensively studied in many compounds including $\mathrm{Ca}_{9} \mathrm{La}\left(\mathrm{PO}_{4}\right)_{7}: \mathrm{Eu}^{2+}, \mathrm{Mn}^{2+},{ }^{19} \mathrm{Ca}_{9} \mathrm{Ln}\left(\mathrm{PO}_{4}\right)_{7}: \mathrm{Tb}^{3+}$ (with $\mathrm{Ln}=$ $\mathrm{Y}$, La or $\mathrm{Gd}){ }^{20} \mathrm{Ca}_{9} \mathrm{Bi}\left(\mathrm{PO}_{4}\right)_{7}: \mathrm{Ce}^{3+}, \mathrm{Tb}^{3+}, \mathrm{Mn}^{2+}, \mathrm{Ca}_{9} \operatorname{LiGd}(2 / 3)$ $\left(\mathrm{PO}_{4}\right)_{7}: \mathrm{Eu}^{2+},{ }^{22} \mathrm{Sr}_{8} \mathrm{MgLn}\left(\mathrm{PO}_{4}\right)_{7}: \mathrm{Eu}^{2+}$ (with $\mathrm{Ln}=\mathrm{Y}$ or La) ${ }^{23}$ and $\mathrm{Sr}_{9}{ }^{-}$ $\mathrm{Sc}\left(\mathrm{PO}_{4}\right)_{7}: \mathrm{Eu}^{2+}, \mathrm{Mn}^{2+} \cdot{ }^{24}$ Yet, the crystal structure and luminescence properties of $\mathrm{Ca}_{9} \mathrm{La}\left(\mathrm{PO}_{4}\right)_{7}: \mathrm{Sm}^{3+}$ were seldomly reported before.

In this article, orange-red single-phase $\mathrm{Ca}_{9} \mathrm{La}\left(\mathrm{PO}_{4}\right)_{7}: \mathrm{Sm}^{3+}$ phosphors were fabricated via solid state reaction. Then their crystal structure and photoluminescence performance were discussed in detail. Beside that, thermal quenching, lifetime and concentration quenching were also investigated. The energy transfer in $\mathrm{Ca}_{9} \mathrm{La}\left(\mathrm{PO}_{4}\right)_{7}$ doped with $\mathrm{Sm}^{3+}$ were also detailly examined, which demonstrated the feasibility of $\mathrm{Ca}_{9}$ $\mathrm{La}\left(\mathrm{PO}_{4}\right)_{7}: \mathrm{Sm}^{3+}$ phosphors applied in n-UV or blue light excited $\mathrm{w}$-LEDs as orange-red emitters. 


\section{Experimental methods}

\subsection{Materials and synthesis}

A series of $\mathrm{Ca}_{9} \mathrm{La}_{1-x}\left(\mathrm{PO}_{4}\right)_{7}: x \mathrm{Sm}^{3+}(x=0.01,0.03,0.06,0.09,0.12$, $0.15,0.18$ and 0.25 ) were fabricated via high temperature solidstate reaction with following precursors: $\mathrm{CaCO}_{3}$ (Aladdin, 99.9\%), $\mathrm{NH}_{4} \mathrm{H}_{2} \mathrm{PO}_{4}$ (Aladdin, 99.9\%), $\mathrm{La}_{2} \mathrm{O}_{3}$ (Aladdin, 99.99\%) and $\mathrm{Sm}_{2} \mathrm{O}_{3}$ (Aladdin, 99.99\%). Each reactant of stoichiometric amount was fully grinded and preheated at $650{ }^{\circ} \mathrm{C}$ for $6 \mathrm{~h}$. Then, the mixture was heated at $1300{ }^{\circ} \mathrm{C}$ for $4 \mathrm{~h}$. After cooling down to room temperature and grinding, the products were obtained.

\subsection{Characterizations}

Powder X-ray diffraction (XRD) data was acquired from a Bruker D8 Advance $\mathrm{X}$-ray powder diffractometer, using $\mathrm{Cu} \mathrm{K} \alpha$ radiation $(\lambda=1.5418 \AA)$ with operation voltage of $40 \mathrm{kV}$ and current of 40 $\mathrm{mA}$. Then, Rietveld analysis was performed on XRD data (step size: $0.02^{\circ}$, counting time: $2 \mathrm{~s}$ per step, and $2 \theta: 5^{\circ}-120^{\circ}$ )

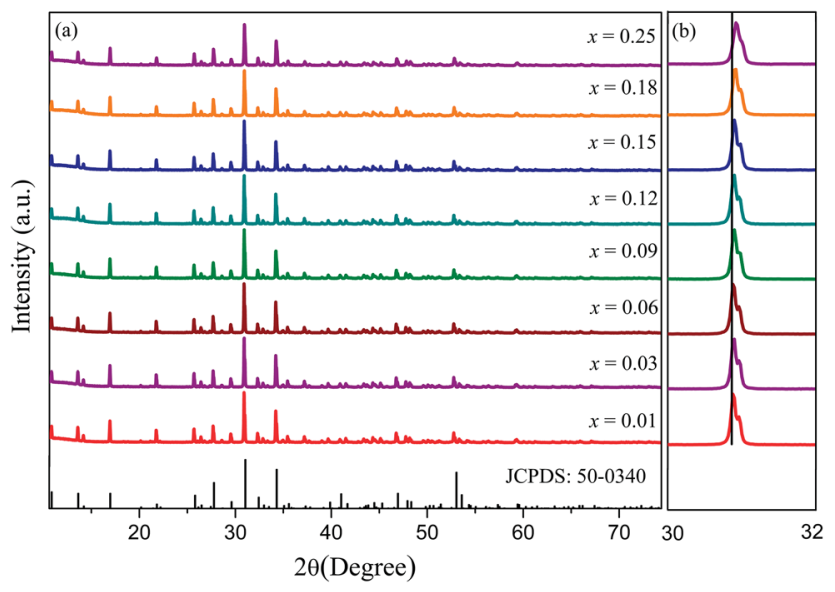

Fig. 1 X-ray diffraction patterns of $\mathrm{Ca}_{9} \mathrm{La}_{1-x}\left(\mathrm{PO}_{4}\right)_{7}: x \mathrm{Sm}^{3+}(x=0.01$ $0.03,0.06,0.09,0.12,0.15,0.18$ and 0.25$)$ phosphors and the polycrystalline standard card of $\mathrm{Ca}_{9} \mathrm{Sc}\left(\mathrm{PO}_{4}\right)_{7}$ (JCPDS no. 50-0340) as a reference $(\mathrm{a})$, the zoomed area $2 \theta=30-32^{\circ}$ of the patterns(b). collected from $\mathrm{Ca}_{9} \mathrm{La}_{0.99}\left(\mathrm{PO}_{4}\right)_{7}: 0.01 \mathrm{Sm}^{3+}$ and $\mathrm{Ca}_{9} \mathrm{La}_{0.88^{-}}$ $\left(\mathrm{PO}_{4}\right)_{7}: 0.12 \mathrm{Sm}^{3+}$ phosphors. TOPAS program was used to perform crystal structure refinement. ${ }^{25}$ And photoluminescence emission (PL) and excitation (PLE) spectra, as well as temperature-dependent luminescence properties were all obtained by a Hitachi F-4600 fluorescence spectrophotometer. In addition, the decay curves were detected by a Yvon TBXPS spectrofluorometer. ZEISS 6035 scanning electron microscope (SEM) equipped with an Inca X-Max energy dispersive spectroscope (EDS) operated at voltage of $20 \mathrm{kV}$ was used to characterize the particle morphology and conduct elemental analysis.

\section{Results and discussion}

\subsection{Crystal structure}

XRD patterns for samples $\mathrm{Ca}_{9} \mathrm{La}_{1-x}\left(\mathrm{PO}_{4}\right)_{7}: x \mathrm{Sm}^{3+}(x=0.01,0.03$, $0.06,0.09,0.12,0.15,0.18$ and 0.25 ) were shown in Fig. 1 , and due to the isostructure, the polycrystalline standard data of compound $\mathrm{Ca}_{9} \mathrm{Sc}\left(\mathrm{PO}_{4}\right)_{7}$ (JCPDS: 50-0340) was taken as a reference. As can be seen from the Fig. 1, all the diffraction peaks of the phosphors perfectly matched with the reference, suggesting that the prepared phosphors was a single phase and that the introduction of $\mathrm{Sm}^{3+}$ ions did not sensibly influence the crystal lattice of $\mathrm{Ca}_{9} \mathrm{La}\left(\mathrm{PO}_{4}\right)_{7}$. Besides, considering the similar ionic radius and the same valence state, the $\mathrm{Sm}^{3+}$ ions were thought to take up the La sites. Moreover, the diffraction peaks position slightly shifted toward higher angles along with the raised $\mathrm{Sm}^{3+}$ doping concentration (Fig. 1(b)), which also confirmed the occupation of $\mathrm{La}^{3+}$ ions by smaller $\mathrm{Sm}^{3+}$ ions. To further verify the purity of $\mathrm{Ca}_{9} \mathrm{La}_{1-x}\left(\mathrm{PO}_{4}\right)_{7}: x \mathrm{Sm}^{3+}$ compounds, Rietveld refinement was performed on $x=0.01$ and $x=0.12$ samples at room temperature. The initial structural model for Rietveld refinement was constructed based on isostructural single crystal crystallographic data of $\mathrm{Ca}_{9} \mathrm{Sc}\left(\mathrm{PO}_{4}\right)_{7}$. And Fig. 2 showed Rietveld refinement results on $x=0.01$ (Fig. 2(a)) and $x=0.12$ (Fig. 2(b)) samples using TOPAS 4.2. The original experimental patterns were indicated by black circles and diamonds, the calculated patterns were represented by solid lines. The difference between them were shown in purple and blue curves, the
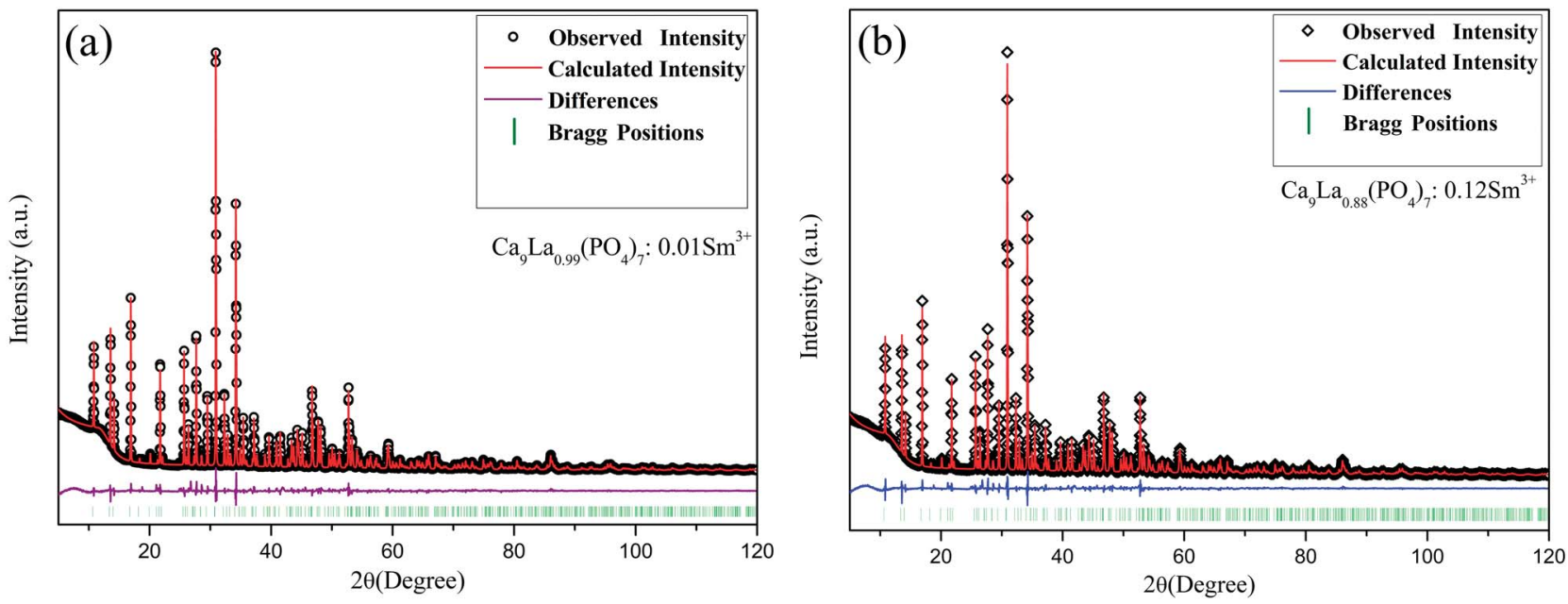

Fig. 2 Rietveld refinement of the XRD profile of $x=0.01$ (a) and $x=0.12$ (b). 
Table 1 Main parameters of processing and refinement of the $x=0.01$ and 0.12 sample

\begin{tabular}{lll}
\hline Compound & $\mathrm{Ca}_{9} \mathrm{La}_{0.99}\left(\mathrm{PO}_{4}\right)_{7}: 0.01 \mathrm{Sm}^{3+}$ & $\mathrm{Ca}_{9} \mathrm{La}_{0.88}\left(\mathrm{PO}_{4}\right)_{7}: 0.12 \mathrm{Sm}^{3+}$ \\
\hline 20-interval & $5-120\left(^{\circ}\right)$ & $5-120\left(^{\circ}\right)$ \\
Space group & $R 3 c(161)$ & $R 3 c(161)$ \\
Symmetry & Rhombohedral & Rhombohedral \\
Cell & $a(\AA)=10.48233(9) ;$ & $a(\AA)=10.48020(9) ;$ \\
parameters & $c(\AA)=37.5409(4) ;$ & $c(\AA)=37.5334(4) ;$ \\
& $V\left(\AA^{3}\right)=3572.32(7)$ & $V\left(\AA^{3}\right)=3570.16(7)$ \\
Reliability & $Z=6$ & $Z=6$ \\
factors & $R_{\mathrm{p}}=3.90$ & $R_{\mathrm{p}}=3.861$ \\
& $R_{\mathrm{wp}}=5.77$ & $R_{\mathrm{wp}}=5.43$ \\
& $R_{\exp }=1.44$ & $R_{\exp }=1.42$ \\
& $R_{\mathrm{Bragg}}=1.79$ & $R_{\mathrm{Bragg}}=1.59$ \\
& $x^{2}=1.60$ & $x^{2}=1.46$ \\
& &
\end{tabular}

calculated Bragg reflections positions of $\mathrm{Ca}_{9} \mathrm{Sc}\left(\mathrm{PO}_{4}\right)_{7}$ was shown in olive vertical lines. As shown in Table 1 and Fig. 2, the refinements possessed low R-factors. The reliability parameters finally converged to $R_{\mathrm{wp}}=5.77 \%, R_{\mathrm{p}}=3.90 \%$ and $x^{2}=1.60$ for $x$ $=0.01$ and $R_{\mathrm{wp}}=5.43 \%, R_{\mathrm{p}}=3.86 \%$ and $x^{2}=1.46$ for $x=0.12$ phosphors, indicating that both samples were pure single phase. Besides, the results listed in Table 1 showed that the samples were well crystallized in an rhombohedral lattice with the space group of $R 3 c$. Interestingly, the cell volume dropped with the increasing of doping $x$, which was because of the smaller ion radius of $\mathrm{Sm}^{3+}$ compared to $\mathrm{La}^{3+}\left(3572.32 \AA^{3}\right.$ for $x=$ 0.01 and $3570.16 \AA^{3}$ for $x=0.12$ ).

Fig. 3 showed the details of the reference $\mathrm{Ca}_{9} \mathrm{La}\left(\mathrm{PO}_{4}\right)_{7}$ crystal structure based on $\beta-\mathrm{Ca}_{3}\left(\mathrm{PO}_{4}\right)_{2},{ }^{26}$ and it was obvious that
$\mathrm{Ca}_{9} \mathrm{La}\left(\mathrm{PO}_{4}\right)_{7}$ was isostructural to $\mathrm{Ca}_{9} \mathrm{Sc}\left(\mathrm{PO}_{4}\right)_{7}$ and $\mathrm{Ca}_{9}-$ $\mathrm{Fe}\left(\mathrm{PO}_{4}\right)_{7} \cdot{ }^{27,28}$ In particular, three different $\mathrm{Ca}^{2+}$ ionic sites and only one kind of $\mathrm{La}^{3+}$ site were observed. More specifically, the three kinds of $\mathrm{Ca}^{2+}$ ionic sites were all coordinated with eight oxygen atoms, while the $\mathrm{La}^{3+}$ site was coordinated with six oxygen atoms. This could further explain why the $\mathrm{Sm}^{3+}\left(r\left(\mathrm{Sm}^{3+}\right)\right.$ $=0.958 \AA, \mathrm{CN}=6)$ ions occupied the sites of the $\mathrm{La}^{3+}\left(r\left(\mathrm{La}^{3+}\right)=\right.$ $1.032 \AA \mathrm{CN}=6$ ), as described in Fig. 1 .

Fig. 4 displayed the SEM image of the $x=0.12$ phosphor including the EDS elemental analysis in the red rectangle area. The irregular particle size and the agglomeration occurred during the heating process were the typical morphology from high temperature solid-state reaction synthesis. ${ }^{5}$ Meanwhile, the EDS analysis showed that the atom ratio of each element $\mathrm{Ca}$, $\mathrm{La}, \mathrm{O}, \mathrm{P}$ and Sm were 9.11, 0.83, 28.37, 7.06 and 0.14 at\%, respectively. The results indicated the actual atom ratio of each element was very close to the intended atom ratio, and also confirmed the success of Sm doping.

\subsection{Luminescence properties}

For the purpose of investigation on the luminescence properties of $\mathrm{Sm}^{3+}$ in $\mathrm{Ca}_{9} \mathrm{La}\left(\mathrm{PO}_{4}\right)_{7}$, the PLE spectra at different emission wavelengths $\left(\lambda_{\mathrm{em}}=570,607,653 \mathrm{~nm}\right)$ and PL spectra under different excitation wavelengths $\left(\lambda_{\mathrm{ex}}=377,406,408 \mathrm{~nm}\right)$ of $x=$ 0.12 sample were monitored under the same testing conditions as shown in the Fig. 5. All the excitation spectra as well as emission spectra possessed the same features except for the discrepancy in relative intensities. The PL spectra also indicated that $\mathrm{Ca}_{9} \mathrm{La}\left(\mathrm{PO}_{4}\right)_{7}: \mathrm{Sm}^{3+}$ compounds had potential to be applied as near-UV light $(350-420 \mathrm{~nm})$ excited phosphor, since the

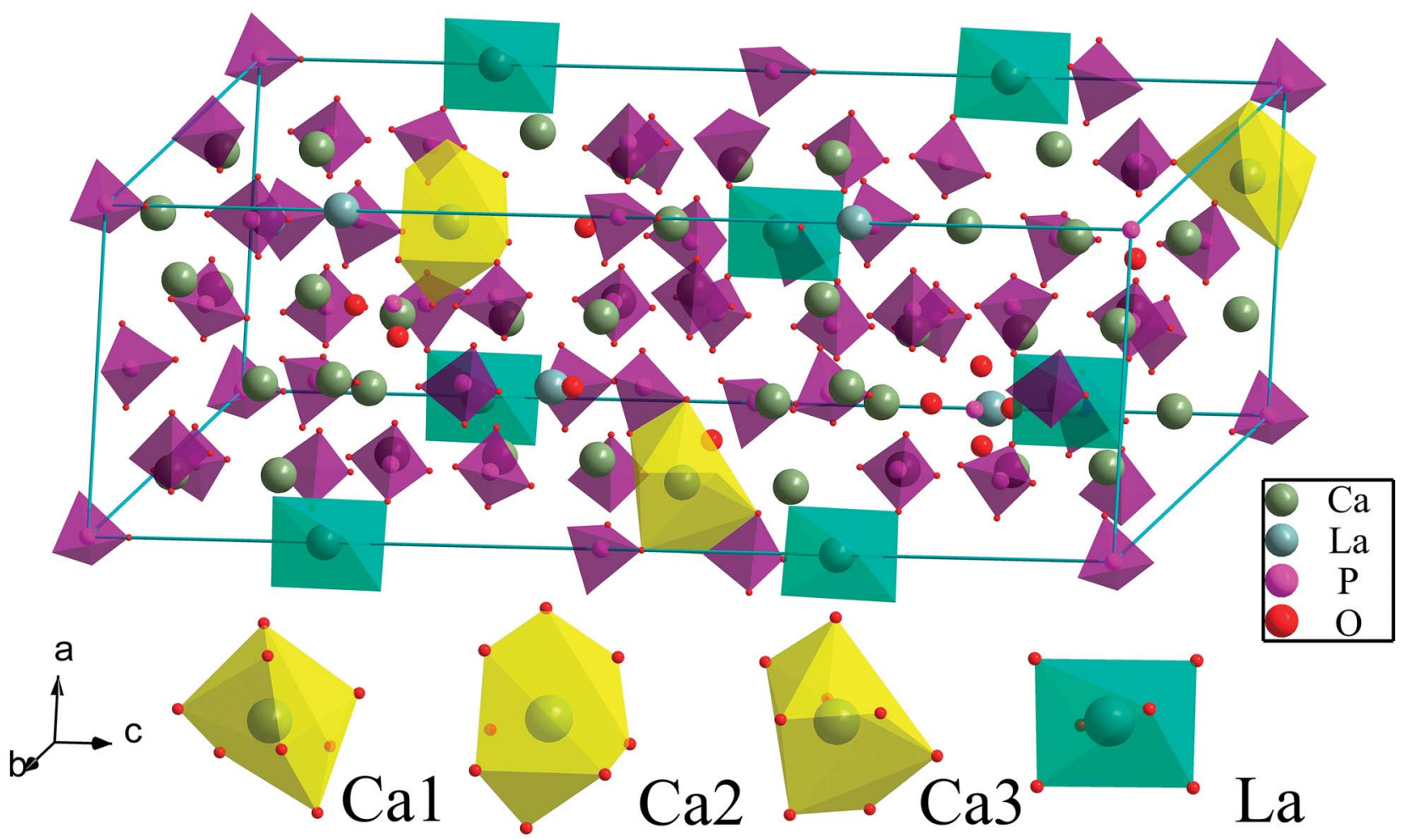

Fig. 3 Simulated crystal structure of $\mathrm{Ca} a_{9} \mathrm{La}\left(\mathrm{PO}_{4}\right)_{7}$ compound. 


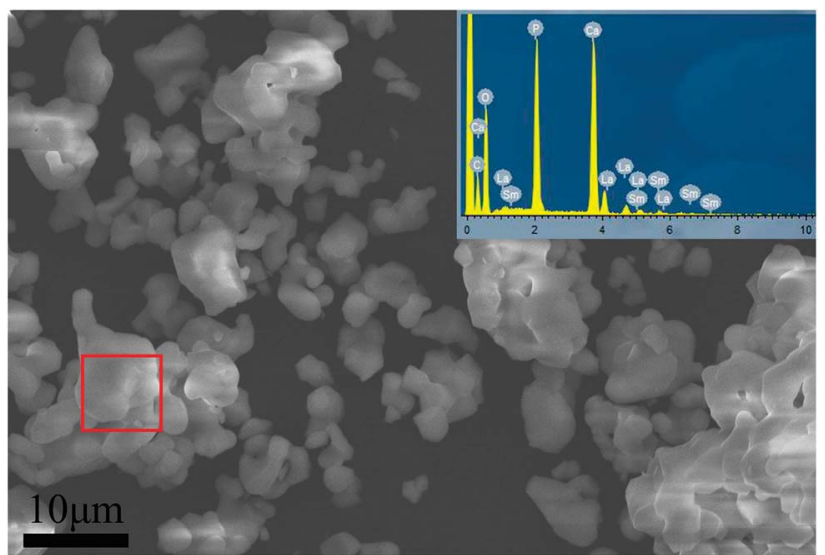

Fig. 4 SEM image of $x=0.12$ sample, the EDS element analysis of the surface points within the rectangle area is shown in the inset.

emission intensities were maximal under the excitation at $406 \mathrm{~nm}$.

The PLE spectrum in Fig. 5(a) clearly was made up of multiple narrow bands (at 320,347, 365, 377, 406, and $478 \mathrm{~nm}$ ) in the wavelength range from 300 to $500 \mathrm{~nm}$, which were corresponding to the following transitions of $\mathrm{Sm}^{3+}$ ions: ${ }^{6} \mathrm{H}_{5 / 2} \rightarrow$ ${ }^{2} \mathrm{~L}_{15 / 2},{ }^{6} \mathrm{H}_{5 / 2} \rightarrow{ }^{4} \mathrm{H}_{9 / 2},{ }^{6} \mathrm{H}_{5 / 2} \rightarrow{ }^{4} \mathrm{D}_{3 / 2},{ }^{6} \mathrm{H}_{5 / 2} \rightarrow{ }^{4} \mathrm{D}_{1 / 2},{ }^{6} \mathrm{H}_{5 / 2} \rightarrow{ }^{4} \mathrm{~F}_{7 / 2}$ and ${ }^{6} \mathrm{H}_{5 / 2} \rightarrow{ }^{4} \mathrm{I}_{11 / 2} \cdot{ }^{4,29}$ Among them, by analyzing the integrated areas of every narrow peaks, it was manifested that the ${ }^{4} \mathrm{~F}_{7 / 2}$ was the most populated level under the excitation at $406 \mathrm{~nm}$. The PL bands maxima in Fig. 5(b) were centered at 570, 607, 653, and $714 \mathrm{~nm}$, corresponding to the ${ }^{4} \mathrm{G}_{5 / 2} \rightarrow{ }^{6} \mathrm{H}_{5 / 2},{ }^{4} \mathrm{G}_{5 / 2} \rightarrow{ }^{6} \mathrm{H}_{7 / 2},{ }^{4} \mathrm{G}_{5 /}$ ${ }_{2} \rightarrow{ }^{6} \mathrm{H}_{9 / 2}$ and ${ }^{4} \mathrm{G}_{5 / 2} \rightarrow{ }^{6} \mathrm{H}_{11 / 2}$ transitions of $\mathrm{Sm}^{3+}$, ${ }^{5,30}$ respectively. Likewise, among these transitions, it was indicated the ${ }^{4} \mathrm{G}_{5 / 2} \rightarrow{ }^{6} \mathrm{H}_{7 / 2}$ (at $607 \mathrm{~nm}$ ) transition was the most intense one by the integrated areas analysis. And according to the selection rules, this was a partially magnetic and partially electric dipole transition, ${ }^{31}$ while ${ }^{4} \mathrm{G}_{5 / 2} \rightarrow{ }^{6} \mathrm{H}_{9 / 2}$ as well as ${ }^{4} \mathrm{G}_{5 / 2} \rightarrow{ }^{6} \mathrm{H}_{11 / 2}$ was purely electric dipole transitions and ${ }^{4} \mathrm{G}_{5 / 2} \rightarrow{ }^{6} \mathrm{H}_{5 / 2}$ was purely magnetic dipole transition. ${ }^{4}$

For a better understanding of the luminescence behaviors of $\mathrm{Sm}^{3+}$ in $\mathrm{Ca}_{9} \mathrm{La}\left(\mathrm{PO}_{4}\right)_{7}$, the energy level diagram of $\mathrm{Sm}^{3+}$ was shown in Fig. 5(c). According to the diagram, $\mathrm{Sm}^{3+}$ ions can be excited to the ${ }^{4} \mathrm{~F}_{7 / 2},{ }^{4} \mathrm{D}_{1 / 2}$ and ${ }^{4} \mathrm{I}_{11 / 2}$ states from the ${ }^{6} \mathrm{H}_{5 / 2}$, and the states were relaxed to the ${ }^{4} \mathrm{G}_{5 / 2}$ emitting state through nonradiative (NR) transitions. The efficient multi-channel transition emissions of $\mathrm{Sm}^{3+}$ ions occurred when the ${ }^{4} \mathrm{G}_{5 / 2}$ state was populated. As a result, $\mathrm{Sm}^{3+}$ exhibited visible emitting colors.

In order to identify the optimal $\mathrm{Sm}^{3+}$ doping content and clarify the dependence of the emission intensities on the $\mathrm{Sm}^{3+}$ concentration, the optical properties of a series of $\mathrm{Ca}_{9} \mathrm{La}_{1-x^{-}}$ $\left(\mathrm{PO}_{4}\right)_{7}: x \mathrm{Sm}^{3+}$ phosphors $(x=0.01,0.03,0.06,0.09,0.12,0.15$, 0.18 and 0.25 ) were investigated. And Fig. 6 showed the emission spectra under $406 \mathrm{~nm}$ excitation. The intensities of emission peaks initially increased with the enhanced $\mathrm{Sm}^{3+}$ doping content and reached a maximum value at the $\mathrm{Sm}^{3+}$ content of $0.12 \mathrm{~mol}$, and then decreased due to the concentration quenching. According to ref. 32 and 33, the critical energy transfer distance $R_{\mathrm{C}}$ between $\mathrm{Sm}^{3+}$ ions can be calculated according to the concentration quench formula:

$$
R_{\mathrm{C}} \approx 2\left[\frac{3 V}{4 \pi x_{\mathrm{c}} N}\right]^{1 / 3}
$$

where $N$ represented for the value of available sites in the unit cell which could be occupied by $\mathrm{Sm}^{3+}$ ions, $x_{\mathrm{c}}$ for the critical concentration of $\mathrm{Sm}^{3+}$ ions and $V$ for the volume of the unit cell. For $\mathrm{Ca}_{9} \mathrm{La}_{1-x}\left(\mathrm{PO}_{4}\right)_{7}: x \mathrm{Sm}^{3+}$ phosphors, $N=54, V=3570.16 \AA^{3}$ and $x_{\mathrm{c}}=0.12$. As a result, the approximate value of $R_{\mathrm{C}}$ was calculated as $10.17 \AA$, which was more than $0.5 \mathrm{~nm}$. Thus, the mechanism behind energy transfer between $\mathrm{Sm}^{3+}$ ions in $\mathrm{Ca}_{9}-$ $\mathrm{La}\left(\mathrm{PO}_{4}\right)_{7}: \mathrm{Sm}^{3+}$ phosphors was determined as electric multipolar interaction.

According to Dexter theory, this kind of interaction between sensitizer and activator can be further analyzed based on the calculation from the following equation: ${ }^{34,35}$

$$
\frac{I}{x}=K\left[1+\beta(x)^{\frac{\theta}{3}}\right]^{-1}
$$

where $\theta$ stands for an indicator of the electric multipolar character, $x$ for the activator content, $K$ and $\beta$ for the constants in the same excitation conditions for a given host lattice and $I$ for the integral intensity of the emission spectra. Most importantly, $\theta$ values of 6,8 and 10 referred to dipole-dipole, dipole-quadrupole and quadrupole-quadrupole interactions, respectively. Additionally, the relationship between $\log (I / x)$ and $\log x$
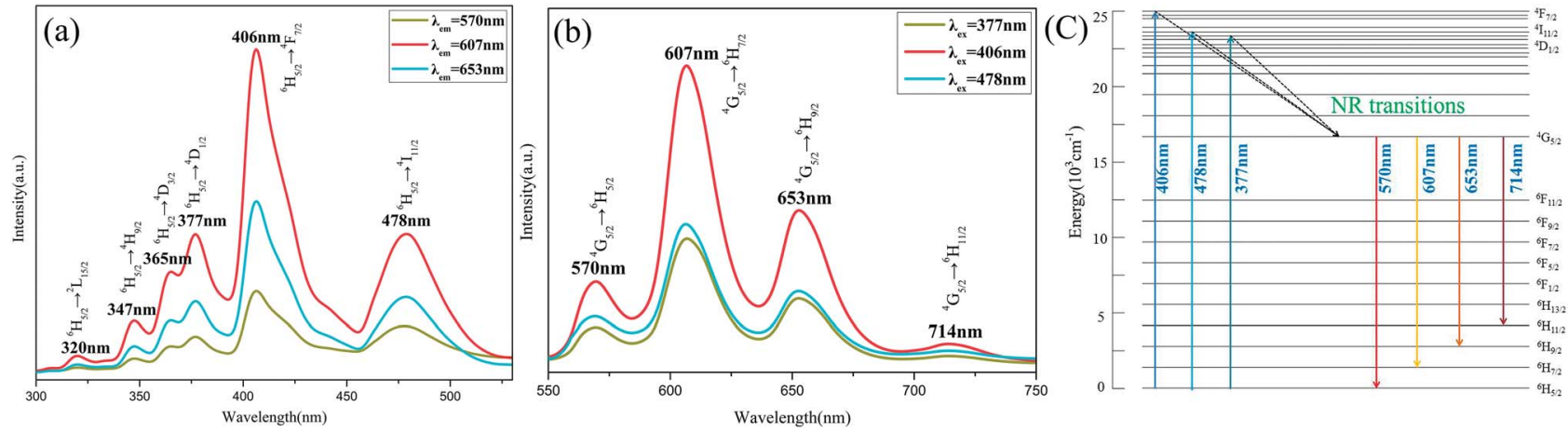

Fig. 5 PLE spectrum $\left(\lambda_{\text {em }}=570,607,653 \mathrm{~nm}\right)$ included transitions: ${ }^{6} \mathrm{H}_{5 / 2} \rightarrow{ }^{2} \mathrm{~L}_{15 / 2},{ }^{4} \mathrm{H}_{9 / 2},{ }^{4} \mathrm{D}_{3 / 2},{ }^{4} \mathrm{D}_{1 / 2},{ }^{4} \mathrm{~F}_{7 / 2}$ and ${ }^{4} \mathrm{I}_{11 / 2}(\mathrm{a}), \mathrm{PL}$ spectrum $\left(\lambda_{\mathrm{ex}}=377\right.$, 406, $478 \mathrm{~nm}$ ) included transitions: ${ }^{4} \mathrm{G}_{5 / 2} \rightarrow{ }^{6} \mathrm{H}_{5 / 2},{ }^{6} \mathrm{H}_{7 / 2},{ }^{6} \mathrm{H}_{9 / 2}$ and ${ }^{6} \mathrm{H}_{11 / 2}$ of $x=0.12$ sample (b) and the energy level diagram of Sm ${ }^{3+}$ in $\mathrm{Ca}_{9}-$ $\mathrm{La}\left(\mathrm{PO}_{4}\right)_{7}$ (c). 

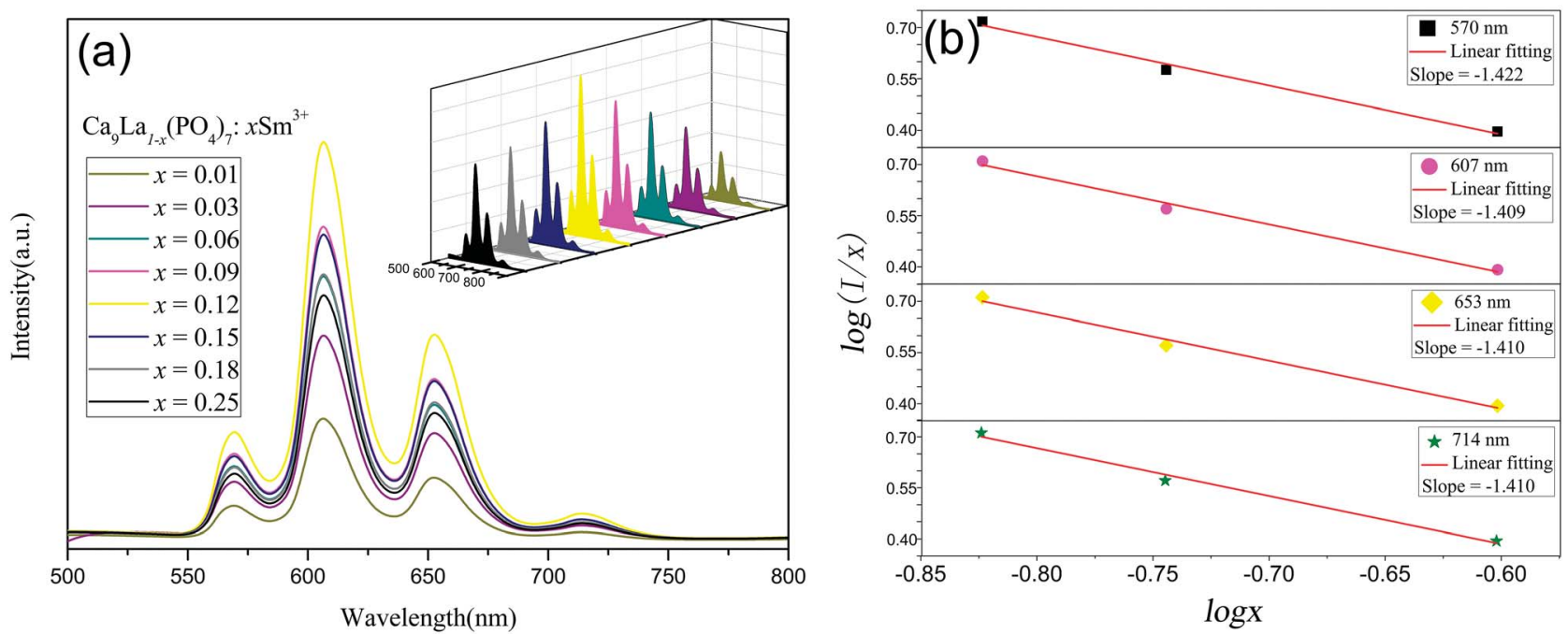

Fig. $6 \mathrm{PL}$ spectrum $\left(\lambda_{\mathrm{ex}}=406 \mathrm{~nm}\right)$ of $\mathrm{Ca}_{9} \mathrm{La}_{1-x}\left(\mathrm{PO}_{4}\right)_{7}: x \mathrm{Sm}^{3+}$ phosphors (a), The relationship between log $(/ / x)$ versus log $x$ in $\mathrm{Sm}^{3+}$ doped $\mathrm{Ca} \mathrm{La}\left(\mathrm{PO}_{4}\right)_{7}$ phosphors (b).

obtained in $\mathrm{Sm}^{3+}$ doped $\mathrm{Ca}_{9} \mathrm{La}\left(\mathrm{PO}_{4}\right)_{7}$ phosphors at $406 \mathrm{~nm}$ exicitation was displayed in Fig. 6(b). The slope (equal to $\theta / 3$ ) was $-1.422,-1.409,-1.410$, and -1.410 , indicated that the $\theta$ values were $4.266,4.227,4.230$ and 4.230 , respectively. These values close to 6 revealed that the principal concentration quenching mechanism behind the luminescence quenching of $\mathrm{Ca}_{9} \mathrm{La}_{1-x}\left(\mathrm{PO}_{4}\right)_{7}: x \mathrm{Sm}^{3+}$ phosphors was the dipole-dipole interaction.

To further investigate luminescence properties, Fig. 7 showed the fluorescence decay curves of $\mathrm{Ca}_{9} \mathrm{La}_{1-x}\left(\mathrm{PO}_{4}\right)_{7}: x \mathrm{Sm}^{3+}$ phosphors $(x=0.03,0.12$, and 0.25$)$ under $406 \mathrm{~nm}$ excitation and monitored at 570, 607 and $653 \mathrm{~nm}$. Each curve exhibited a single - exponential decay and could be calculated by the following equation: ${ }^{5}$

$$
I(t)=I_{0}+A_{1} \exp (-t / \tau)
$$

where $I(t)$ and $I_{0}$ represent the intensity at time $t$ and $0, A_{1}$ is a constant, $t$ stands for time, $\tau$ is the decay time for an exponential component. The lifetimes of $\mathrm{Sm}^{3+}$ monitored at $607 \mathrm{~nm}$ resulting from eqn (3), were $1.52,1.19$ and $0.75 \mathrm{~ms}$. That monitored at $653 \mathrm{~nm}$ were 1.50, 1.18 and $0.75 \mathrm{~ms}$. Meanwhile, the lifetimes monitored at $570 \mathrm{~nm}$ were $1.49,1.17$ and $0.74 \mathrm{~ms}$. All the results indicating a shorten lifetime with the increasing $\mathrm{Sm}^{3+}$ concentration, which further proved the energy transfer happened between $\mathrm{Sm}^{3+}$ ions in $\mathrm{Ca}_{9} \mathrm{La}\left(\mathrm{PO}_{4}\right)_{7}$.

As one of the most important parameters for technological utilization of phosphors, thermal stability was also investigated. ${ }^{5}$ The PL spectra $\left(\lambda_{\mathrm{ex}}=406 \mathrm{~nm}\right)$ of $x=0.12$ phosphor within $25-300{ }^{\circ} \mathrm{C}$ were showed in Fig. 8(a) and the relationship between relative emission intensities and the temperature was showed in the inset. Each emission spectrum included the several characteristic peaks of $\mathrm{Sm}^{3+}$ within 500-800 $\mathrm{nm}$. However, the emission intensities declined gradually along with the rising temperature, which was because of the thermal quenching effect. ${ }^{2,5}$ As shown in the inset, the integrated emission intensities of the $x=0.12$ phosphor at $150^{\circ} \mathrm{C}$ was about $79 \%$ of the one at $25{ }^{\circ} \mathrm{C}$, which indicated rather good stability of the phosphor.

To detailly investigate the thermal quenching effect and estimate the activation energy during the quenching process, the variation tendency of the luminescence intensity of $x=0.12$ sample along with changing temperature could be depicted by the Arrhenius equation: ${ }^{36}$
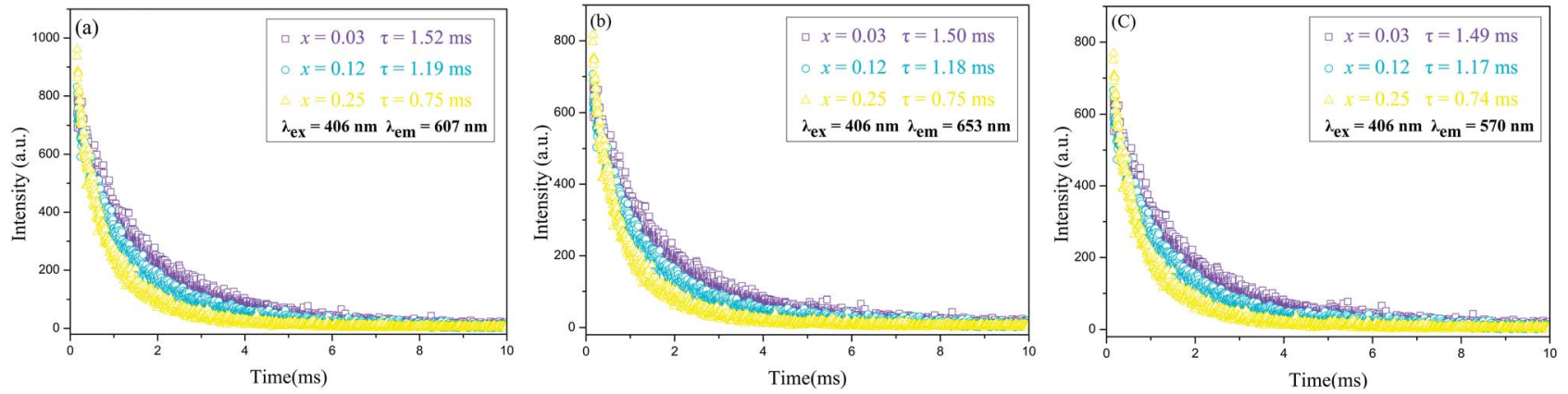

Fig. 7 Decay curves of $\mathrm{Sm}^{3+}$ in $x=0.03,0.12$, and 0.25 phosphors excited at $406 \mathrm{~nm}$ and monitored at 607 (a), 653 (b) and 570 (c) nm. 

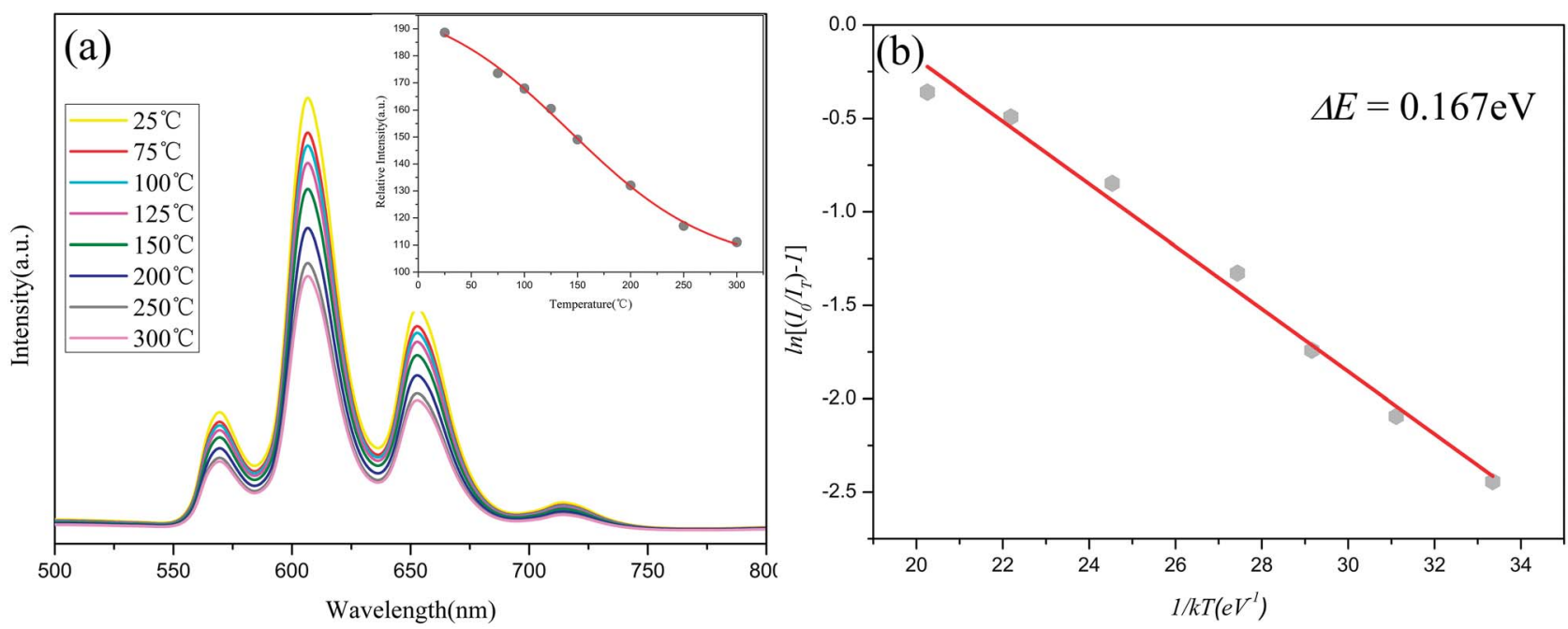

Fig. 8 The PL spectra $\left(\lambda_{\mathrm{ex}}=406 \mathrm{~nm}\right.$ ) of $x=0.12$ phosphor under different temperatures ranging from 30 to $300{ }^{\circ} \mathrm{C}$, and the temperature intensities curve is shown in the inset (a); The Arrhenius fitting of the calculated activation energy for thermal quenching and the emission intensity of $x=0.12$ (b).

$$
I_{\mathrm{T}}=\frac{I_{0}}{1+c \exp (-\Delta E / k T)}
$$

where $I_{0}$ represented for the initial intensity, $I_{\mathrm{T}}$ for the intensity at a given temperature $T, c$ for a constant, $\Delta E$ for the activation energy for thermal quenching, and $k$ for Boltzmann's constant $\left(8.617 \times 10^{-5} \mathrm{eV} \mathrm{K}^{-1}\right)$. In Fig. $8(\mathrm{~b}), \ln \left[\left(I_{0} / I_{\mathrm{T}}\right)-1\right]$ versus $1 /(k T)$ for the $x=0.12$ sample was plotted, and according to the linear regression, the thermal activation energy $\Delta E$ for quenching process was determined as $0.167 \mathrm{eV}$.

The CIE (Commission Internationale de $\mathrm{L}^{\prime}$ Eclairage) color chromaticity coordinates $(x, y)$ of the $x=0.12$ phosphor

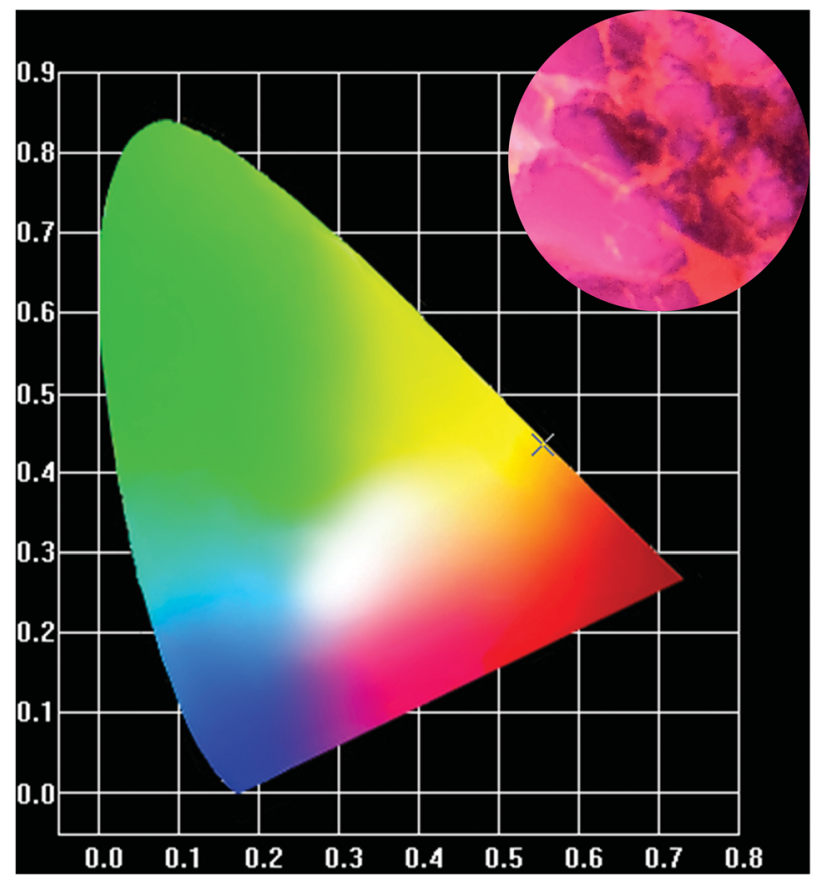

Fig. $9 \mathrm{ClE}$ chromaticity coordinates $\left(\lambda_{\mathrm{ex}}=406 \mathrm{~nm}\right)$ and the digital image of $x=0.12$ phosphor. acquired from the PL spectra under $406 \mathrm{~nm}$ excitation were labelled with a cross symbol in the CIE chromaticity diagram, as showed in Fig. 9. The resulting coordinates $(0.5548,0.4358)$ indicated the emission in the orange-red region. For exhibition purpose, the inset in Fig. 9 showed the digital image of the phosphor. Above results suggested that this orange-red phosphors could be promising candidate in w-LEDs excited by n-UV chips.

\section{Conclusions}

In summary, a series of $\mathrm{Ca}_{9} \mathrm{La}_{1-x}\left(\mathrm{PO}_{4}\right)_{7}: x \mathrm{Sm}^{3+}$ phosphors were successfully fabricated via conventional solid-state reaction. The crystal structure, photoluminescence performance, decay lifetime and thermal quenching behaviors were studied in detail. The crystallographic analysis indicated that the doped $\mathrm{Ca}_{9} \mathrm{La}\left(\mathrm{PO}_{4}\right)_{7}: \mathrm{Sm}^{3+}$ compounds crystallized in rhombohedral crystal structure (space group: $R 3 c$ (161)). The PL spectra of $\mathrm{Ca}_{9} \mathrm{La}_{1-x}\left(\mathrm{PO}_{4}\right)_{7}: \mathrm{XSm}^{3+}$ samples were made up of four emission bands around $570,607,653$, and $714 \mathrm{~nm}$, corresponding to the ${ }^{4} \mathrm{G}_{5 / 2} \rightarrow{ }^{6} \mathrm{H}_{\mathrm{J}}(J=5 / 2,7 / 2,9 / 2$, and $11 / 2)$ transitions of $\mathrm{Sm}^{3+}$ ions, respectively. Among them, the ${ }^{6} \mathrm{H}_{7 / 2}$ was the most populated level. The optimal $\mathrm{Sm}^{3+}$ doping content turned out to be $x=0.12 \mathrm{~mol}$, and the critical transfer distance $R_{\mathrm{C}}$ of $\mathrm{Sm}^{3+}$ in $\mathrm{Ca}_{9} \mathrm{La}\left(\mathrm{PO}_{4}\right)_{7}$ was determined as $10.17 \AA$. Besides, On the basis of the Dexter theory, the electric dipole-dipole interaction was determined to be the principal concentration quenching mechanism behind the energy transfer between $\mathrm{Sm}^{3+}$ in $\mathrm{Ca}_{9} \mathrm{La}_{1-x}\left(\mathrm{PO}_{4}\right)_{7}: x \mathrm{Sm}^{3+}$ phosphors. From the life time decay curves that the energy transfer between $\mathrm{Sm}^{3+}$ ions in $\mathrm{Ca}_{9} \mathrm{La}\left(\mathrm{PO}_{4}\right)_{7}$ was also observed. Moreover, $\mathrm{Ca}_{9} \mathrm{La}\left(\mathrm{PO}_{4}\right)_{7}: \mathrm{Sm}^{3+}$ possessed fine thermal and color stability. All the results pointed out that the $\mathrm{Ca}_{9} \mathrm{La}_{1-x}\left(\mathrm{PO}_{4}\right)_{7}: x \mathrm{Sm}^{3+}$ phosphors have great potential as orange-red phosphors for developing wLEDs excited by n-UV radiation. 


\section{Conflicts of interest}

There are no conflicts to declare.

\section{Acknowledgements}

This work is supported by the Qinghai Provincial Natural Science Foundation for Young Scholars (No. 2017-ZJ-929Q) and the Qinghai Provincial Innovation Platform Program (No. 2017ZJ-Y17).

\section{References}

1 J. Zhao, C. Guo, T. Li, X. Su, N. Zhang and J. Chen, Dyes Pigm., 2016, 132, 159-166.

2 B. Ma, Z. Huang, M. Fang, Y. Liu and X. Wu, RSC Adv., 2015, 5, 9933-9938.

3 H. Liu, L. Liao, M. S. Molokeev, Q. Guo, Y. Zhang and L. Mei, RSC Adv., 2016, 47, 24577-24583.

4 L. Li, X. Tang, Z. Jiang, X. Zhou, S. Jiang, X. Luo, G. Xiang and K. Zhou, J. Alloys Compd., 2017, 701, 515-523.

5 B. Ma and B. Liu, J. Lumin., 2017, 188, 54-59.

6 X. Mi, J. Sun, P. Zhou, H. Zhou, D. Song, K. Li, M. Shang and J. Lin, J. Mater. Chem. C, 2015, 3, 4471-4481.

7 Z. Xia and A. Meijerink, Chem. Soc. Rev., 2016, 46, 275-299.

8 Q. Zhou, Y. Zhou, Y. Liu, L. Luo, Z. Wang, J. Peng, J. Yan and M. Wu, J. Mater. Chem. C, 2015, 3, 3055-3059.

9 Z. Sun, M. Wang, Z. Yang, Z. Jiang, K. Liu and Z. Ye, J. Alloys Compd., 2016, 658, 453-458.

10 J. Xu, Z. Ju, X. Gao, Y. An, X. Tang and W. Liu, Inorg. Chem., 2013, 52, 13875-13881.

11 J. Du, D. Xu, X. Gao, Z. Yang and J. Sun, J. Mater. Sci.: Mater. Electron., 2017, 28, 8136-8143.

12 Z. Yang, D. Xu and J. Sun, Opt. Express, 2017, 25, A391.

13 P. Biswas, V. Kumar, G. Agarwal, O. M. Ntwaeaborwa and H. C. Swart, Ceram. Int., 2016, 42, 2317-2323.

14 Q. Guo, C. Zhao, L. Liao, S. Lis, H. Liu, L. Mei and Z. Jiang, J. Am. Ceram. Soc., 2017, 100, 2221-2231.

15 X. Dong, J. Zhang, Z. Xia, Z. Hao and Y. Luo, J. Alloys Compd., 2014, 587, 493-496.

16 Y. S. Tang, S. F. Hu, C. C. Lin, N. C. Bagkar and R. S. Liu, Appl. Phys. Lett., 2007, 90, 151103-151108.
17 Z. Wu, J. Liu and M. Gong, Chem. Phys. Lett., 2008, 466, 8890.

18 X. Dong, J. Zhang, Z. Xia, Z. Hao and S. Lv, Ceram. Int., 2014, 40, 5421-5423.

19 C. H. Huang and T. M. Chen, Opt. Express, 2010, 18, 50895099.

20 F. Zhang, J. Xie, G. Li, W. Zhang, Y. Wang, Y. Huang and Y. Tao, J. Mater. Chem. C, 2016, 5, 872-881.

21 K. Li, M. Shang, Y. Zhang, J. Fan, H. Lian and J. Lin, J. Mater. Chem. C, 2015, 3, 7096-7104.

22 F. Du, R. Zhu, Y. Huang, Y. Tao and H. J. Seo, Dalton Trans., 2011, 40, 11433-11440.

23 C. H. Huang and T. M. Chen, Inorg. Chem., 2011, 50, 57255730.

24 X. Dong, J. Zhang, L. Zhang, X. Zhang, Z. Hao and Y. Luo, Eur. J. Inorg. Chem., 2013, 2014, 870-874.

25 V. TOPAS, Bruker AXS, Karlsruhe, Germany, 2008.

26 A. A. Belik, F. Izumi, T. Ikeda, M. Okui, A. P. Malakho, V. A. Morozov and B. I. Lazoryak, J. Solid State Chem., 2002, 168, 237-244.

27 H. F. Li, Y. L. Jia, T. F. Ma, R. Pang, W. Z. Sun, D. Li, J. P. Fu, S. Zhang, L. H. Jiang and C. Y. Li, Eur. J. Inorg. Chem., 2016, 2016, 867-873.

28 B. I. Lazoryak, V. A. Morozov, A. A. Belik, S. S. Khasanov and V. S. Shekhtman, J. Solid State Chem., 1996, 122, 15-21.

29 R. Yu, N. Xue, T. Wang, Z. Zhao, J. Wang, Z. Hei, M. Li, H. M. Noh and J. H. Jeong, Ceram. Int., 2015, 41, 6030-6036.

30 Y. Liu, P. Yang, W. Wang, H. Dong and J. Lin, CrystEngComm, 2010, 12, 3717-3723.

31 B. Bondzior, D. Stefańska, A. Kubiak and P. J. Dereń, J. Lumin., 2016, 173, 38-43.

32 G. Blasse, Phys. Lett. A, 1968, 28, 444-445.

33 G. Blasse, J. Solid State Chem., 1986, 62, 207-211.

34 D. L. Dexter, J. Chem. Phys., 1953, 21, 836-850.

35 B. Ma, Q. Guo, M. S. Molokeev, Z. Lv, J. Yao, L. Mei and Z. Huang, Ceram. Int., 2016, 42, 5995-5999.

36 S. Arrhenius, Über die Dissociationswärme und den Einfluss der Temperatur auf den Dissociationsgrad der Elektrolyte, Wilhelm Engelmann, 1889. 